\title{
充填層反応装置によるトリメチレンジアミンとエチレングリコールの気相反応1)
}

岡田寿太郎，中野功一，土屋裕弘，塚本豊久 京都大学薬学部 ${ }^{2)}$

\section{Gas Phase Reaction of Trimethylenediamine and Ethylene Glycol in the Reacter packed with Catalysts ${ }^{1)}$}

\author{
Jutarô Okada, Koichi Nakano, Michiniro Tsuchiya and Toyohisa Tsukamoto \\ Faculty of Pharmaceutical Sciences, Kyoto University')
}

(Received March 22; 1975)

\begin{abstract}
Hexahydro-2-methylpyrimidine was prepared in a good yield and selectively by gas phase reaction of trimethylenediamine with ethylene glycol. The reaction was carried out over 10 kinds of silica-alumina catalysts within the temperature range of $220-440^{\circ}$. They were Neobead (I), $5 \% \quad \mathrm{~K}_{2} \mathrm{O}$-Neobead (II), $6.8 \% \quad \mathrm{Cr}_{2} \mathrm{O}_{3}$-Neobead (III), synthetic zeolite (IV), $5 \% \mathrm{~K}_{2} \mathrm{O}$-synthetic zeolite (V), natural zeolite (Clinoptilolite, Itaya, Yamagata) (VI), $5 \% \mathrm{SiO}_{2}+95 \% \mathrm{Al}_{2} \mathrm{O}_{3}$ (VII), $30 \% \mathrm{SiO}_{2}+70 \% \mathrm{Al}_{2} \mathrm{O}_{3}$ (VIII), $50 \% \mathrm{SiO}_{2}+50 \% \mathrm{Al}_{2} \mathrm{O}_{3}$ (IX), and $70 \% \mathrm{SiO}_{2}+30 \% \mathrm{Al}_{2} \mathrm{O}_{3}(\mathrm{X})$. Yield and selectivity of a series of zeolites were higher than that of Neobeads.

The yield and selectivity were higher in case of catalysts VII, VIII, IX, and X when $\mathrm{SiO}_{2}$ content was larger. Among all these catalysts, VI gave the best yield of hexahydro2-methylpyrimidine, which was $65 \%$ under the condition of molar ratio of $1: 3$, for feed rate of materials of $1 \mathrm{ml} / \mathrm{min}$, weight of packed catalyst of $30 \mathrm{~g}$, and reaction temperature of $315^{\circ}$.
\end{abstract}

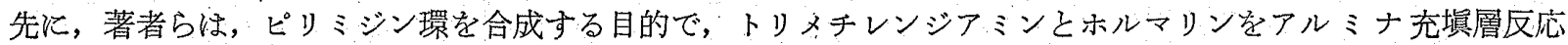
装置を用いて気相で反応させ，へキサハイドロ-1-メチルピリミジンとへキサハイドロ-1,3-ジメチルピリミジン が，高收率で選択的に得られることを報告した。.3)

今回，同様の反応装置を用い，ホルマリンの代わりにエチレングリコールを用いて，トリメチレンジアミンど 反応させたところ，へキサハイドロー2-メチルピリミジンが約 $50 \%$ の高収率で選択的に得られた。

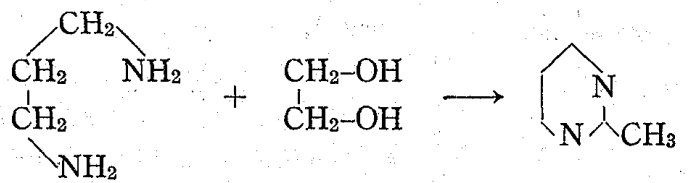

ヘキサハイドロ-2-メチルピリミジンは，従来，液相でトリメチレンジアミンとアセトアルデヒドによる縮合反 応により得られているが，その収率は約 $5 \%$ である.4

それに比し，本反応は，高収率でしかもワンステップで極めて短時間に反応が進行し，連続的に生成物が得ら えるという利点がある。

そこで，生成物の収率をさらに上昇さ䢊る目的で，触媒，反応温度，接触時間，原料の組成此などのフっク ターを変化させて反応を行ない，以下の知見を得た。

\section{実 験 の 部}

（1）実験装置と操作方法 使用した装置と操作方法は前報 ${ }^{3)}$ と同様である。

1) 第 24 回日本薬学会近畿支部総会, 大阪，1974 年 11 月，に和いて発表.

2) Location: Yoshida-Shimoadachi-cho, Sakyo-ku, Kyoto.

3）岡田寿太郎，中野功一，土屋裕弘，薬誌，93，1463 (1973).

4) R.F. Evans, Australian J. Chem., 20, 1643 (1967). 
TABLE I. Composition and Specific Surface ${ }^{a)}$

\begin{tabular}{rccc}
\hline & \multicolumn{2}{c}{ Composition (wt\%) } & $\begin{array}{c}\text { Specific surface } \\
\text { BET method }\left(\mathrm{m}^{2} / \mathrm{g}\right)\end{array}$ \\
\hline & $\mathrm{SiO}_{2} \mathrm{Al}_{2} \mathrm{O}_{3}$ & 177.6 \\
\hline (a) & 5 & 95 & 187.5 \\
(b) & 30 & 70 & 187.7 \\
(c) & 50 & 50 & 196.1 \\
(d) & 70 & 30 & \\
\hline
\end{tabular}

a) measured by Mr. Komatsu

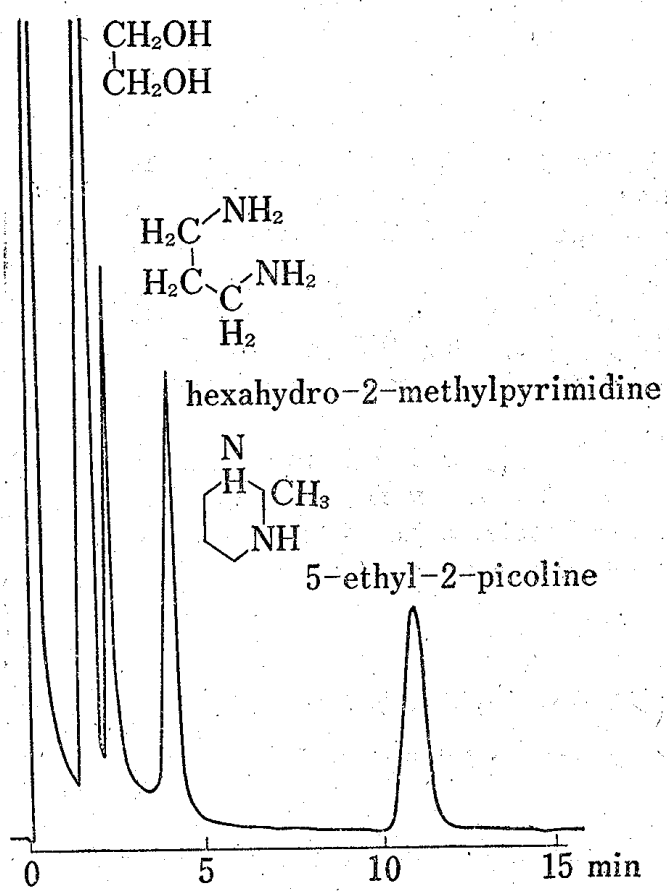

Fig. 1. Quantitative Analysis

column: Silicon DC $55020 \%$ on Celite $545 \quad 60-80$ mesh, $2 \mathrm{~m}, 3 \mathrm{~mm} \phi$ column temp: $100^{\circ}$, detect. temp: $250^{\circ}$ inject. temp: $250^{\circ}$ carrier gas: $\mathrm{He} 27.5 \mathrm{ml} / \mathrm{min}$ bridge current: $80 \mathrm{~mA}$

(4) 生成物の定性

(2) 原料 市貶の無水トリメチレンジアミン（以下 TMDA と記す) と無水ェチレングリコール（以下 EG と 䛌す)とを種々のモル比に混合し：これを3.64 倍モルの水 で希釈して供給した。

な拉，水での希䆏倍率を 10 . 倍モルにしても，収率への 影響はほとんどなく，逆に水で希釈しない時は，反応温度 の調節が困難であった。

（3）触媒 (i) Neobead一水沢化学 (株) 製の Neobead D-4 $\left(\mathrm{SiO}_{2} ; 10 \%, \mathrm{Al}_{2} \mathrm{O}_{3} ; 90 \%\right)$ を粉砕して 9.2-16 mesh に調製したものを使用。

(ii) $6.8 \% \mathrm{Cr}_{2} \mathrm{O}_{3}$-Neobead- $\left(\mathrm{NH}_{4}\right)_{2} \mathrm{Cr}_{2} \mathrm{O}_{7}$ の水溶液に所 定量の Neobead を加えて一昼夜放直. 水浴上で蒸発乾固. $110^{\circ}$ で 3 時間乾喿し，空気を送りながら゙，450 で 3 時間 焼成後使用。

(iii) $5 \% \mathrm{~K}_{2} \mathrm{O}$-Neobead- $\mathrm{KOH}$ 水溶液に所定量の Neobead を加えて，以下 (ii) 之同様に処理して使用.

(iv) 合成ゼオライト (S.Z) 一一鉄興社（株）製の合成ゼオ ライト F-9 (8-12 mesh) をそのまま使用

(v) $5 \% \mathrm{~K}_{2} \mathrm{O}$-合成ゼオライト $\left(5 \% \mathrm{~K}_{2} \mathrm{O}-\mathrm{S} . \mathrm{Z}\right)-\mathrm{KOH}$ 水 溶液飞. S.Z を 3 尽夜放置後, 洗浄. 以下 (ii) と同様に処 理乙て使用.

(vi) 板谷産天然ゼオ.ライ (N.Z)一山形大学工学部高 坂樹夫教授より提供頂いたものを，そのまま使用 $(9.2-16$ mesh).

(vii) $\mathrm{Al}_{2} \mathrm{O}_{3}$ と $\mathrm{SiO}_{2}$ の組成比の異なる触媒一何れる日 本ルッホ（株）小松雄介氏より提供頂いたるのを，450艺 3 時間空気を送りながら筧成後使用: この分析値特よび比表 面積は Table I のとおりである.

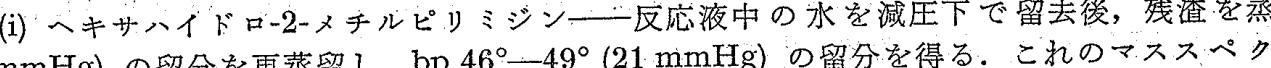
留し, bp $59^{\circ}-66^{\circ}(28 \mathrm{mmHg})$ の留分を再蒸留し, bp $46^{\circ}-49^{\circ}(21 \mathrm{~mm}$ トル $(m / e: 100)$, 核磁気共鳴 (NMR) $\left(\mathrm{D}_{2} \mathrm{O}\right)$ ，赤外線吸収 (IR) スペクトルよりこの物質をへキサハイドロー2ーメ チルピリミジンと確認。

(ii) $\beta$-ピコリソ一一応液をク口ロホルムで抽出し，クロ口ホルムを留去後，残渣を減圧蒸留し，bp $52^{\circ}$ (28一-30 mmHg) の留分を再蒸留. bp $39^{\circ}(22 \mathrm{mmHg})$ の留分を得る。この物質を, $\beta$-ピコリン標準品のIR, 紫 外線吸收 (UV) スペクトルと同定.

(5) 生成物と原料の定量 液体として採取した反応物中のへキサハイドロ-2-メチルピリミジン, $\beta$-ピコリン と未反応の原料などについて，柳本製作所製のガスクロマトグラフィーGCG 550Tを用いて定量した。 Fig. 1 は，定量ガスクロマトグラムの一例である。

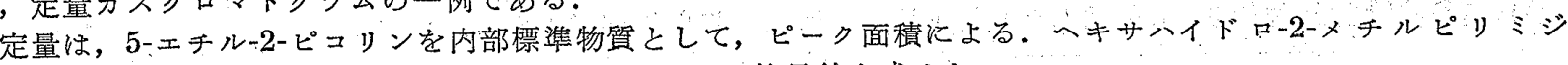
ン, $\beta$ ーピコリン, TMDA, EG 各々についてめらかじめ検量線を求めた。

な蛒，收率は，TMDA を基準にして，次のように計算した。

$$
\text { 収率= } \left.\frac{\text { 単位時間に生成したへキサハイドロー2-メチルピリミジンのモル数 }}{\text { 単位時間に供給したTMDA のモル数 }} \times 100 （ \%\right)
$$


実験結果と考察

(1) 予備実験

Neobead 系,シリカ・アルミナ系の触媒は，使用の最初活性が強く，原料特よび生成物の分解が激しかったの で，1日目に約 8 時間 TMDA と EG を水で希秎した原料で反応を行なって aging した後，2日目から定量に 用いた。

一方，ゼオライト系の触媒は，活性に変化がみられなかったので，1日目から使用。

すべての触媒でとの後の活性の経時変化は認められなかった。

また，空試験として，触媒の代わりに，ラッシヒリングを充填して反応したところ，へキサハイドロー2゙メチル ピリミジンは全く得られず, 原料が回収された。

\section{(2) 触媒と反応温度の影響}

一般に，脱水反応では，触媒の酸性点が反応飞関与していると考光られるので, Neobead 系触媒として，Neobead と $5 \% \mathrm{~K}_{2} \mathrm{O}$ でアルカリ処理した Neobead，また脱水素活性を強めるために，6.8\% $\mathrm{Cr}_{2} \mathrm{O}_{3}$-Neobead を用 いた.

一方，ゼオライト系触媒としては，山形具板谷産天 然ゼオライト (N.Z) と， 合成ゼオライト（S.Z)を用 いた.

まず，モル比 (TMDA/EG) $=1 / 2.24$, 触媒充垻量 $30 \mathrm{~g}$, 流量 $2 \mathrm{ml} / \mathrm{min}$ の条件で反応を行ない, 生成す るヘキサハイドロ-2-メチルピリミジンの收率を検討し た. Fig. 2 は, その結果である。

また. Fig. 3a,bは，この時の TMDA とEGの 減少の樣子を検討したものである。

Fig. 2, Fig. 3a，b から, 次のことが明らかとなっ た。

(i) Neobead 系触媒 Neobead 系触媒では, Neobead は低以収率走示 乙; $\mathrm{K}_{2} \mathrm{O}-\mathrm{Neobead}, \mathrm{Cr}_{2} \mathrm{O}_{3}$-Neo-

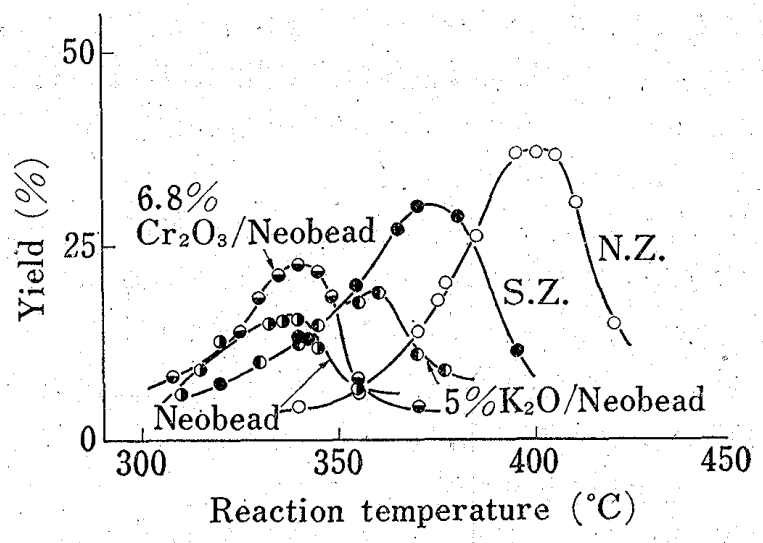

Fig. 2. Effect of Catalysts and Reaction Temperature

TMDA/EG $=1 / 2.24$ Cat. $: 30.0 \mathrm{~g} F=2.0 \mathrm{ml} / \mathrm{min}$ a)

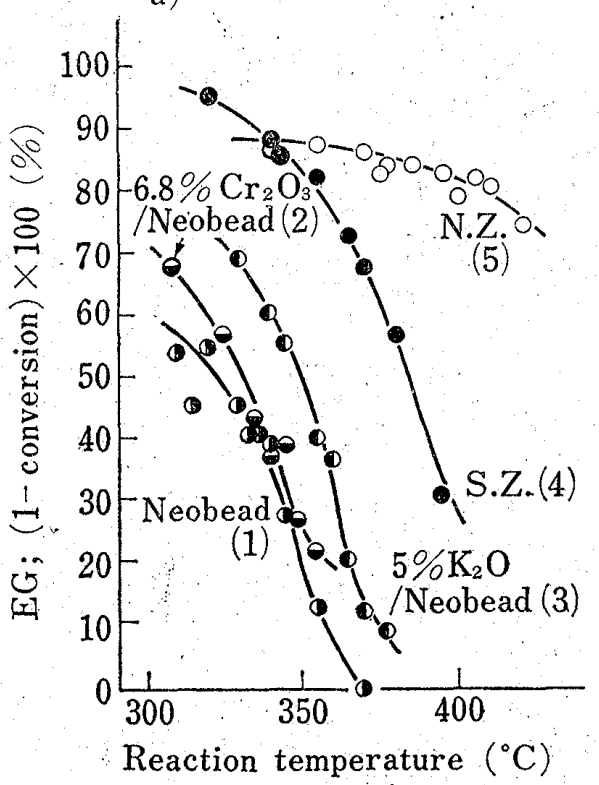

Fig. 3a) (1-Conversion) of $E G$

TMDA $/ E G=1 / 2.24$ Cat.: $30.0 \mathrm{~g} \quad F=2.0 \mathrm{ml} / \mathrm{min}$

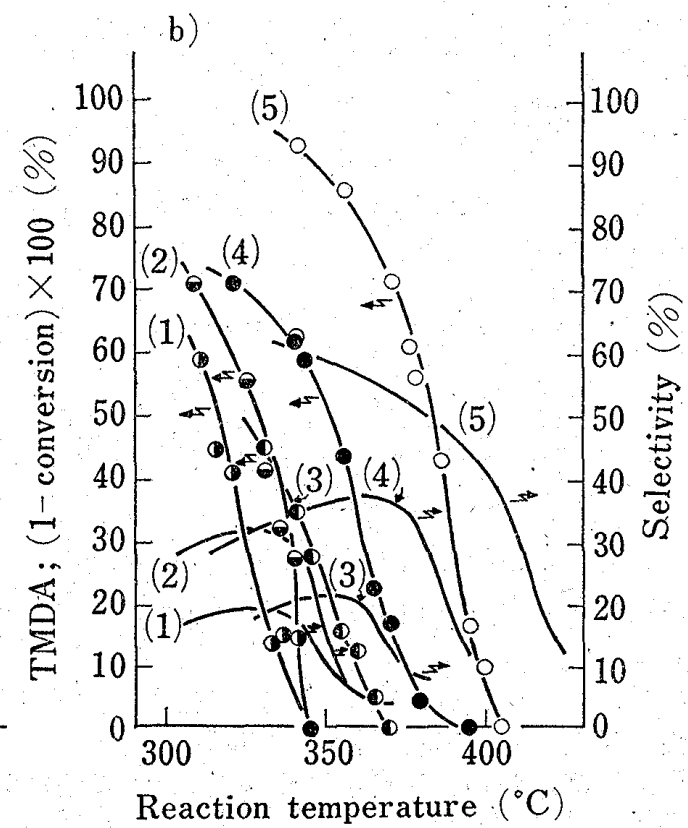

Fig. $3 \mathrm{~b})$ (1-Conversion) of TMDA and Selectivity TMDA/EG $=1 / 2.24$ Cat.: $30.0 \mathrm{~g} \quad F=2.0 \mathrm{ml} / \mathrm{min}$ 
bead の方が，収率は若干高くなっている.

また。 EG, TMDA の残存率をみると, Neobead 系は, 同傾向を示して括り，いずれも $\mathrm{Neobead} \mathrm{Cr}_{2} \mathrm{O}_{3}$ Neobead, $\mathrm{K}_{2} \mathrm{O}$-Neobead の順で高くなっている.

しかしながら, Neobead 系では，収率，原料残存率とすゼオライト系に比べ，低い值を示している.

すなわち, Neobead は, 原料の分解が激しくて, 収率, 原料残存率ともに低い。

ところで，越後谷, ${ }^{5}$. 斯波 ${ }^{6}$ (らは，アセトニトリル合成用触媒にアルカリを添加して副反応を和さえ，収率，選 択率の上昇をはかっている. 本反応で， $5 \% \mathrm{~K}_{2} \mathrm{O}-\mathrm{Neobead}$ を用いた場合，原料の分解はする程度执さえられ， 選択率は高くなっているが，収率はあまり高くなっていない。

$6.8 \% \mathrm{Cr}_{2} \mathrm{O}_{3}$-Neobead では, TMDA, EG の残存率は高くなり, 収率, 選択率が若干上昇している.

(ii) ゼオライト系触媒 ゼオライト系触媒は, Neobead 系の触媒に比べ, 高収率を示し, 最適温度も50 程 度高くなっている。

また，EG，TMDA の残存率は，Neobead系と同傾向を示しているが，ゼオライト系のそれは高く，特に天然 ゼオライトは，高收率を与えるにすかかわらず EG の減少量は少なく，高温ですかなり残っている。

このように，ゼオライト系触媒は，高收率である上，原料の残存率が高く，従って，選択率も高くなっている.

(iii) $\mathrm{SiO}_{2}, \mathrm{Al}_{2} \mathrm{O}_{3}$ の重量組成比の異なる 4 種の触媒 モル比 (TMDA/EG) $=1 / 2.24$, 触媒充填量 $15 \mathrm{~g}$, 流量 $1 \mathrm{ml} / \mathrm{min}$ の条件 $)^{7}$ で， $\mathrm{Al}_{2} \mathrm{O}_{3}$ の重量組成が，95,70,50,30\%の触媒を用いて反応を行ない，その影響を検討 した (Fig. 4).

Table I に示すと拉り 4 種の触媒は， $\mathrm{SiO}_{2}$ の重量比が増すと，表面積が大になっているが；それに伴なって， 低い反応温度で高收率を与え， $\mathrm{SiO}_{2}$ の多い方が，この反応に適していることを示している.

ところで, Holm, ${ }^{8)} \mathrm{Clark}^{9}$ ·らは，種々の組成のシリカ・アルミナを用いて反応を行ない， $\mathrm{SiO}_{2}$ の含量が增す に従って，表面積，弱い酸性点，小さな細孔が増加することを明らかにしている。

従って，本反応です，このようなことが，収率の上昇に奇与しているものと考えられる。

(3) ゼオライト系触媒

そこで，用いた触媒の中で，原料の残存率，收率の高かったゼオライト系触媒と， $5 \% \mathrm{~K}_{2} \mathrm{O}-\mathrm{Neobead}$ を用い，

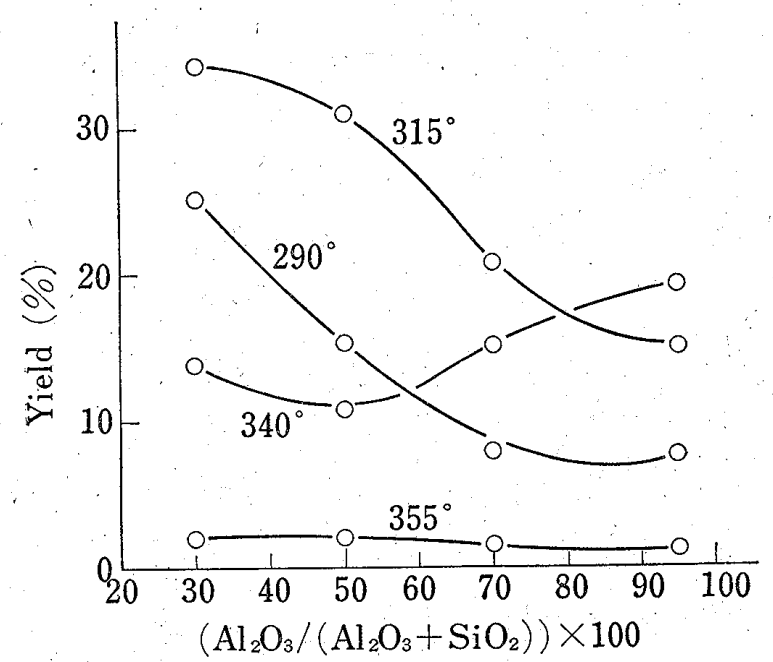

Fig. 4. Effect of Composition of Silica Alumina TMDA/EG $=1 / 2.24$ Cat.: $15.0 \mathrm{~g} \quad F=1.0 \mathrm{ml} / \mathrm{min}$

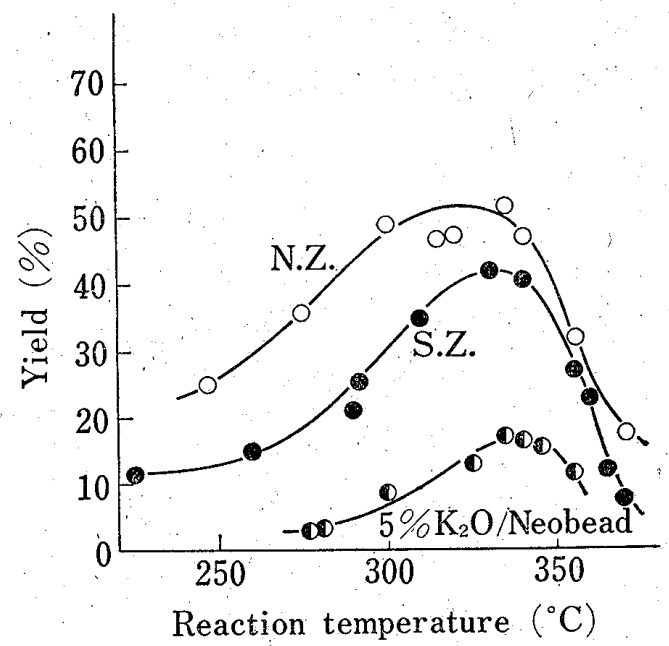

Fig. 5. Effect of Catalysts and Reaction Temperature

TMDA $/ E G=1 / 2.24 \quad$ Cat.: $30.0 \mathrm{~g} \quad F=1.0 \mathrm{ml} / \mathrm{min}$

5) 越後谷悦郎, 小笠原貞夫, 森川 清, 工化, 65, 1360 (1962).

6) 斯波忠夫, 村上雄一, 工化, 60, 9 (1957).

7) これらの触媒は，かさ密度が大きく $30 \mathrm{~g}$ 充填できなかったので， $15 \mathrm{~g}$ とし流量も半分の $1 \mathrm{ml} / \mathrm{min}$ とした.

8) V.C.F. Holm, G.C. Bailey, A. Clark, J. Phys. Chem., 63, 129 (1959).

9) A. Clark, V.C.F. Holm, D.M. Blarkburn, J. Catalysis., 1, 244 (1962); A. Clark, V.C.F. Holm, J. Catalysis,. 2, 16 (1963). 


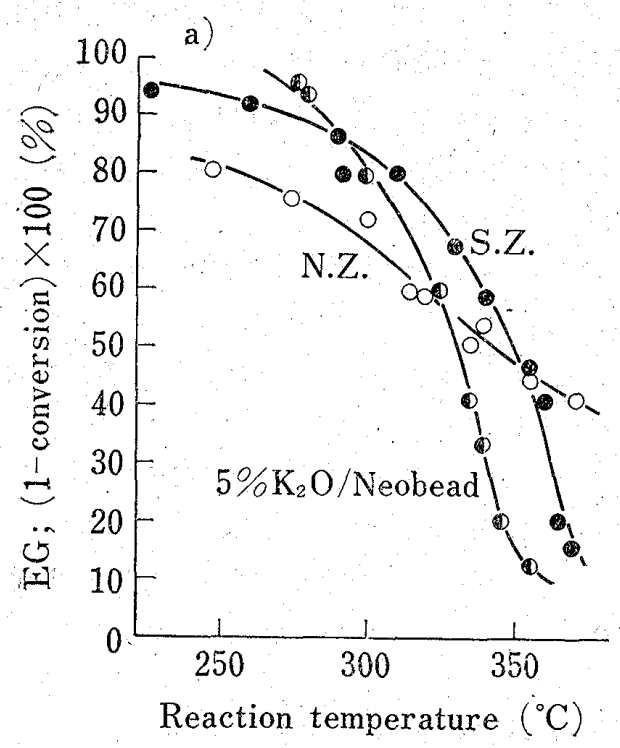

Fig. 6a). (1-Conversion) of EG TMDA/EG $=1 / 2.24 \quad$ Cat. $: 30.0 \mathrm{~g} \quad F=1.0 \mathrm{ml} / \mathrm{min}$ b)

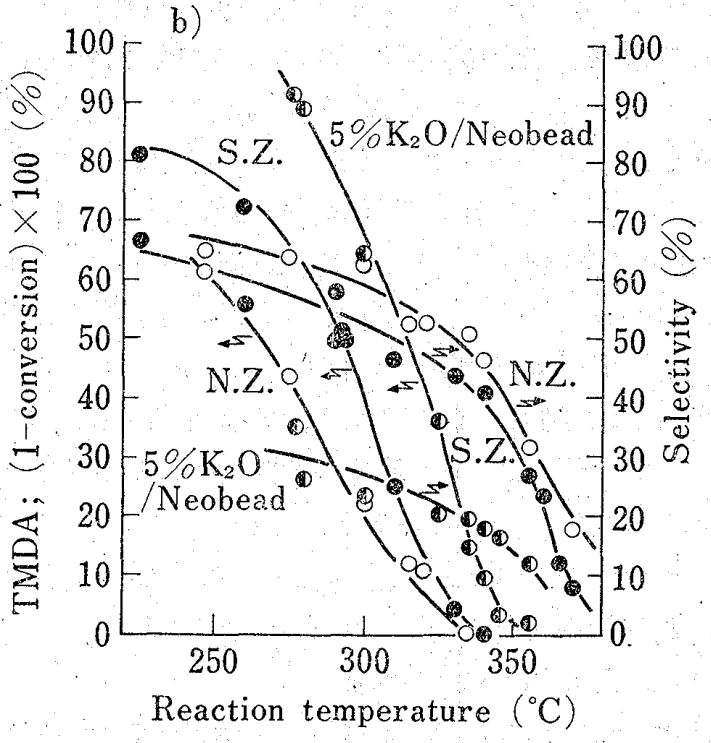

Fig. 6b). (1-Conversion) of TMDA and Selectivity $\mathrm{TMDA} / \mathrm{EG}=1 / 2.24 . \quad$ Cat.: $30.0 \mathrm{~g} \quad F=1.0 \mathrm{ml} / \mathrm{min}$

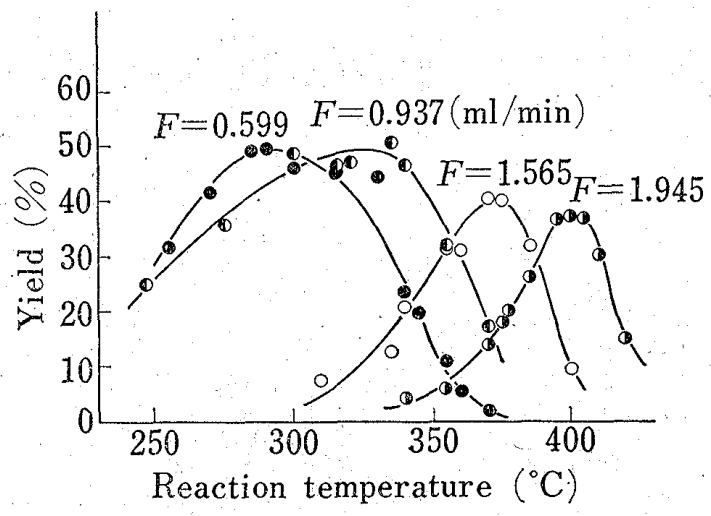

Fig. 8. Effect of Feed Rate TMDA/EG $=1 / 2.24$ Cat.: N.Z. $30.0 \mathrm{~g}$

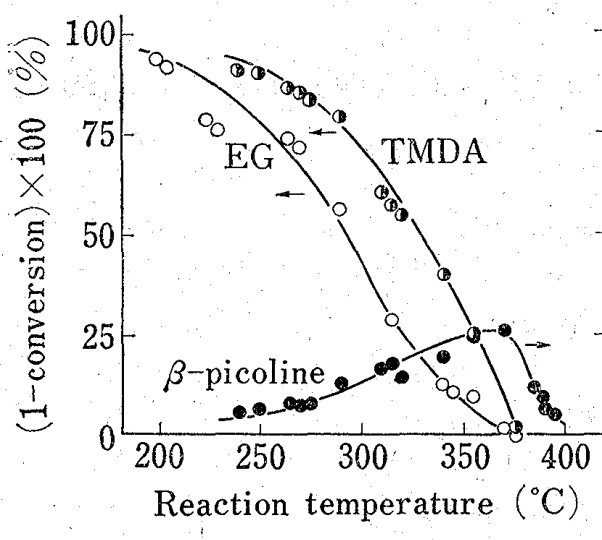

Fig. 7. Effect of Temperature Cat: N.Z. $30.0 \mathrm{~g} . \quad F=1.0 \mathrm{ml} / \mathrm{min}$

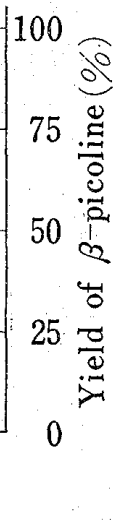

接触時間を 2 倍にして, 反応を行なった。すなわち, モル比 (TMDA/EG) $=1 / 2.24$, 触媒充填量 $30 \mathrm{~g}$, 流量 $1 \mathrm{ml} /$ min の条件で反応し, 収率, 残存率を検討してみた (Fig. 5, Fig. 6a，b).

流量 $2 \mathrm{ml} / \mathrm{min}$ の時に比べ, $5 \% \mathrm{~K}_{2} \mathrm{O}-$ Neobead では, 最高収率はあまり变わらはいが, ゼオライトは，共以 $10 \%$ 程度上昇して，N.Zでは，約 $50 \%$ となった，各触媒とも，350，付近で收率が急激に低下しているのは， 生成物，原料が，このガスクロマトグラムで法検出されない低分子化合物に分解したためと考觉る。

一方, EG の残存率は，3種の触媒とも浪济同傾向であるが，TMDA のそれは，流量 $2 \mathrm{ml} / \mathrm{min}$ の時とは逆 に, $\mathrm{K}_{2} \mathrm{O}-\mathrm{N}$ eobead で高く, N.Z では, 一番低くなっている.Kるかかわらず, N.Z が高収率を示しているのは， 減少した TMDA が，有効に反応使われたことを示している.

この条件でも，TMDA の残存率が 0 となる付近で，最高収率を示している.

以上より，N.Z が高収率，高選択率を与え，本反応に物いて最も有効な触媒であることがわかった。

そこで, N.Z を触媒として, EG, TMDAを，各々単独に反応して，残存率を検討した (Fig. 7).

TMDA のみを水で希釈して供給すると,ンキサハイドロ-2-メチルピリミジンは生成せずに。脱アミノ環化反 疬が進み, $\beta$-ピコリンが得られた。

同じ条件下で, TMDA と EG を原料として反応した時には， $\beta$ ピコリンは全く生成しなかった (Fig. 5). 
ところで，TMDA，EG ともかなりの分解がみられるが，同条件下で，TMDA と EG を原料として反応した 時に比べ, 単独原料の場合の方が, TMDA の残存率は高く, 高温までTMDA が残っている。“をた，EGの残 存率は低く，370。 では 0 となって，分解の激しいことを示しているすなおち，TMDAは；脱了ミノ環化反応 よりも，へキサハイドロ-2-メチルピリミジン生成の方へ寄与し，一方，EG は，TMDA と共存することにより， それ自身の分解が括さえられ，TMDA との反応が進み易くなると考壳られる.

湊ら ${ }^{10)}$ により研究されているこの板谷産天然ゼオライトは，鈆物種的には； clinoptilotite に属しているが， 高シリカ型, 高アルカリ型で， $\mathrm{K}_{2} \mathrm{O}$ に富むといら特徵がある.

そこで， $5 \% \mathrm{~K}_{2} \mathrm{O}-\mathrm{S} . \mathrm{Z}$ を用いて，同条件で反応を行ない，先の S.Z の結果と此較したところ，全体に曲線が 高温側に $35^{\circ}$ 程度移動し，最高取率は，約 $3 \%$ 上昇したにすぎない.

ところで, Benesi ${ }^{11)}$ は，粘土鉣物の酸強度が，シリカ・アルミナに比べ弱いことを明らかにしているが，本 反応では，シリカ含有量の大なることが好適であり，また，N.Zは，高シリカ型である，

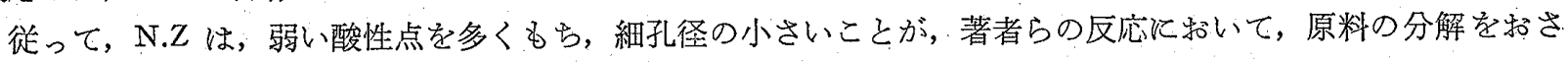
兑，高取率，高選択率を与光ているものと推定する。

\section{(4) 接触時間, 原料の組成比の影響}

そこで，次に N.Ż を用いて，接触洔間と原料の組成比の影響を検討した。

(i) 接触時間の影響 モ゙比 (TMDA/EG) $=1 / 2.24$ ，触媒充填量 $30 \mathrm{~g}$ の条件で，原料の毎分供給量を，0.599． $\mathrm{ml}$ から $1.945 \mathrm{ml}$ まで変化させ，各々について反応温度を变えて，生成するへキサハイドロー2-メチルピリミジ ンの収率を検討した (Fig. 8).

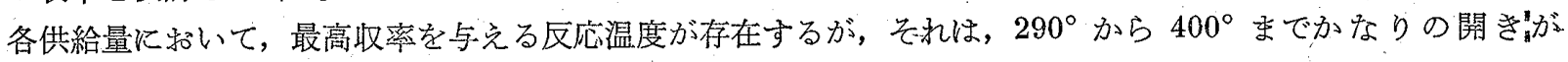
ある。

この場合にも，最高収率を与える温度で，TMDA の残存率は症ば 0 であるが，原料供給量が $1 \mathrm{ml} / \mathrm{min} 以 下$

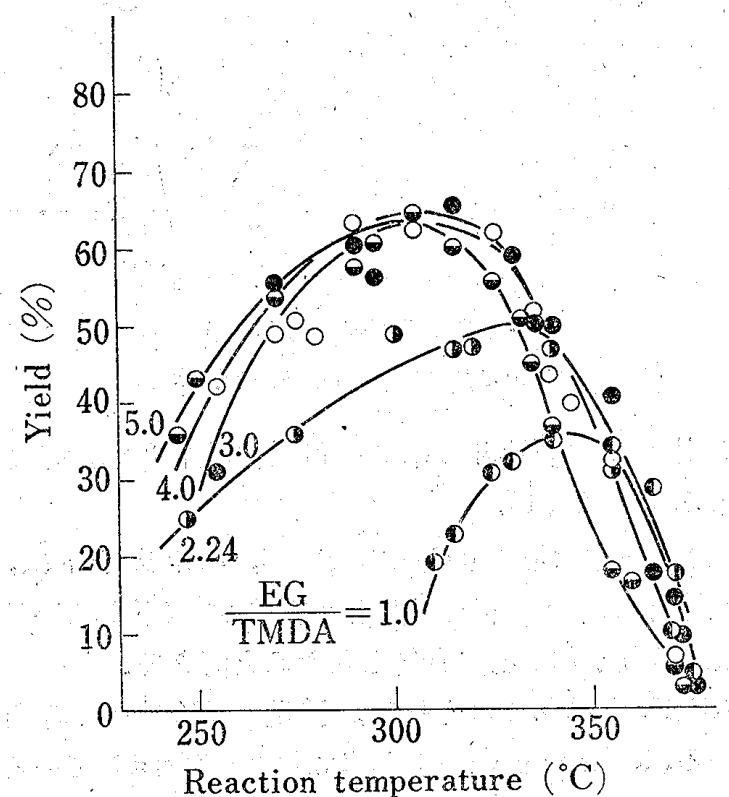

Fig. 9. Effect of Mole Ratio

Cat.: N.Z. $30.0 \mathrm{~g} \quad F=1.0 \mathrm{ml} / \mathrm{min}$

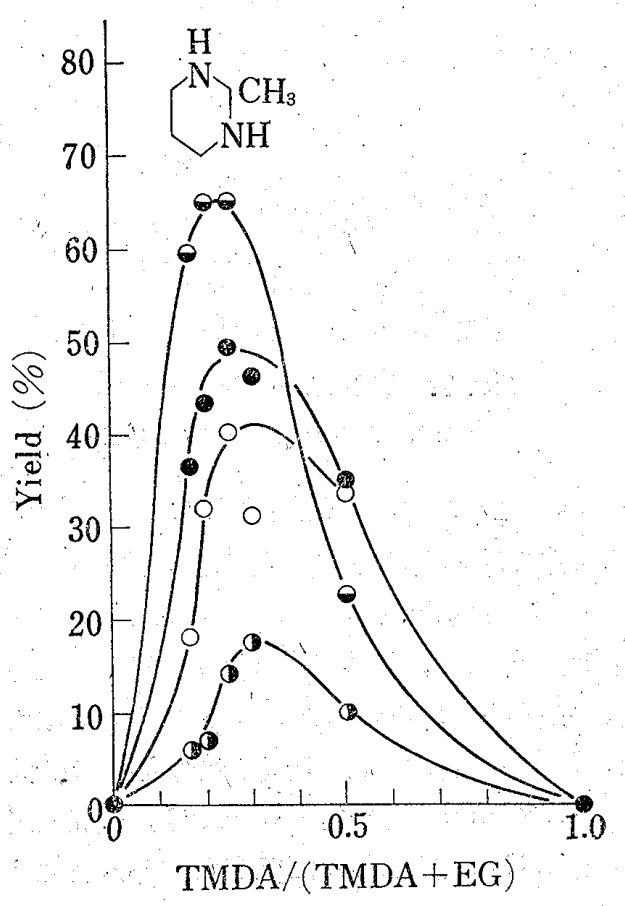

Fig. 10. Effect of Mole Ratio Cat.: N.Z. $30.0 \mathrm{~g} F=1.0 \mathrm{ml} / \mathrm{min}$ Q: $315^{\circ} \cdot 340^{\circ}$ O; $355^{\circ}$ (1): $370^{\circ}$

10) 湊 秀雄, 鉱物学雑誌, 7,14 (1964)；高橋浩他編，“ゼオライトとその利用,”技報堂, 東京, 1968, pp。 $81-91$.

11) H.A, Benesi, J. Phys. Chem., 61, 970 (1957). 
では, 最高收率が一定となっている。

そこで，原料供給量を $1 \mathrm{ml} / \mathrm{min}$ として，原料の組成此の影響を検討した。

(ii) 原料組成比の影響 触媒充填量 $30 \mathrm{~g}$ ，原料供給量 $1.0 \mathrm{ml} / \mathrm{min}$ の条件で，モル比 (EG/TMDA) を1.0, $2.24,3.0,4.0,5.0$ とし，各々について反応温度を変化させて，収率家検討した (Fig. 9).

EG のモル比が大となるに従い，最高収率は上昇するが, 3.0,4.0, 5.0 では, 注とんぞ差が無く, 同傾向を示 して和り，これ以上の EG の增加は分解を招くのみで, へキサハイドロ-2-メチルピリミジンの収率上暴に寄与し ないものと思わ机る。

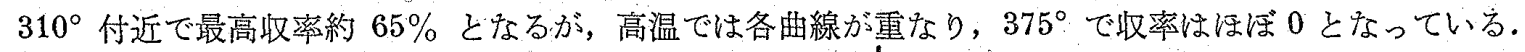

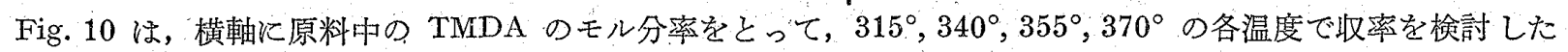
ものである.

いずれの温度に扔いても，原料中の TMDA のモル分率 0 (EG のみ反応した場合) と，モル分率 1 (TMDA のみ反応した場合)では，へキサハイドロー2-メチルピリミジンは生成しない。

TMDA のモル分率 0.2 から 0.3 飞扔いて最高収率を示す。

以上のよう飞, TMDA と EG を板谷産天然ぜオライトを触媒として，モル此 (TMDA/EG) $=1 / 3$, 原料供給 量 $1 \mathrm{ml} / \mathrm{min}$, 触媒充埧量 $30 \mathrm{~g}, 315^{\circ}$ で反応させると, 收率 $65 \%$ 程度で殿択的にへキサハイドロ-2-メチルピリ ミジンを得ることができる。

従来, 天然ゼオライトは製紙用クレー, 工業用・農業用製品として採掘され，ガスの吸着・分離，土塜改良資 材などに利用されているが、反応にはあまり用いられていない、12)

従って，本反応は天然ゼオライトのこのような反応への応用例として，工業的にる興味が持たれる。

謝辞 本研究にあたり，触媒を提供頂いた山形大学工学部高坂彬夫教授，日本ルッボ（株）小松雄介氏に深 謝致します。

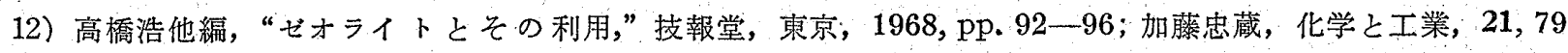
(1968). 